AgAta MATYSIAK-B€ASZCZYK

ORCID 0000-0002-7420-7288

MirosŁaWA ŚCIUPIDER-MŁODKOWSKA

ORCID 0000-0002-8700-2249

Uniwersytet im. Adama Mickiewicza

$w$ Poznaniu

\title{
WYBRANE ASPEKTY \\ REALIZACJI WSPÓŁCZESNYCH RÓL RODZICIELSKICH ZE SZCZEGÓLNYM UWZGLĘDNIENIEM ZNIEWOLONEGO MACIERZYŃSTWA
}

\begin{abstract}
AвSTRACт. Matysiak-Błaszczyk Agata, Ściupider-Młodkowska Mirosława, Wybrane aspekty realizacji wspótczesnych ról rodzicielskich ze szczególnym uwzględnieniem zniewolonego macierzyństwa [Selected Aspects of the Implementation of Contemporary Parental Roles, with Special Emphasis on Enslaved Motherhood]. Studia Edukacyjne nr 56, 2020, Poznań 2020, pp. 185-198. Adam Mickiewicz University Press. ISSN 1233-6688. DOI: 10.14746/se.2020.56.10

This text is intended to reveal selected consequences of parenthood in conditions of permanent social change. The authors of the article have analyzed some of the advantages and disadvantages among the parents, who are the norm and the majority of family relationships, as well as in the minority group, who realize their role of being a mother in a space of total isolation. The first part will reveal a parenthood full of tensions in the face of cultural expectations of the multiplicity of choices. The second part of the text is made up of disadvantages of imprisoned parenthood, exposed to particular pressures and destruction of ties, in the destructive arrangements of mothers serving time with their children.
\end{abstract}

Key words: modern family, enslaved, parenting, prison matherhood, social changes

\section{Wstęp}

Współczesne przemiany związane z rodziną zmuszają rodziców do transfiguracji ról. Paradygmat wielorodzinności w kontrastowym, pełnym niejednoznaczności kolażu więzi i ról społecznych, odsłania blaski i cienie współczesnego rodzicielstwa. Proces socjalizacji dzieci pochodzących z róż- 
nych hybryd, konfiguracji form i kreacji współczesnych wielu rodzin (nie tylko patchworkowych, ale wszelkich alternatywnych do rodziny tradycyjnej wspólnot i więzi rodziców z dzieckiem) jest wielowymiarowy. Z jednej strony, rozwój dziecka przebiega w warunkach wolnych od dyskryminacji i nacisków, ułatwiając partycypację dzieci i rodziców w dokonywaniu wyborów. Z drugiej strony, badacze nauk społecznych i humanistycznych nie ukrywają obaw związanych z ciągłością, stałością i ładem porządkującym strukturę ról w rodzinach mocno zindywidualizowanych i podatnych na konsumpcjonizm $^{1}$. Indywidualizacja życia oraz wszelkie projekty równościowe i emancypacyjne zmieniają wybory na linii partnerstwo-rodzicielstwo, wpływają zarówno na refleksyjność tych wyborów, jak również pokazują, jak bardzo zmienia się rozumienie wspólnotowości ${ }^{2}$. Rodzice są pierwotnym środowiskiem wychowawczym dla dzieci, pełnią swoje role w warunkach wolnych od społecznie i instytucjonalnie narzucanych standardów, z drugiej strony - są nieświadomie uwikłani w niewolę oddziaływania kulturowych kodów i wzorców oraz pozostają zupełnie osamotnieni w dokonaniu wyboru, która droga socjalizacji okaże się najkorzystniejsza dla ich dzieci?

Tekst ten ma na celu ujawnić wybrane skutki rodzicielstwa w warunkach permanentnych zmian społecznych, zarówno wśród rodziców stanowiących normę i większość układów rodzinnych, jak i w grupie mniejszościowej, realizującej swoje role bycia matką w przestrzeni izolacji totalnej. Pierwsza część ujawni rodzicielstwo pełne napięć wobec oczekiwań kulturowych w wielości wyborów. W drugiej części dokonano analizy cieni rodzicielstwa uwięzionego, narażonego na szczególną presję i destrukcję więzi, w niszczycielskich układach współosadzonych matek z dziećmi.

\section{Rodzicielstwo pełne napięć. Oczekiwania kulturowo-społeczne i wielość wyborów}

Dla współczesnych rodziców jedynym kierunkowskazem podejmowania decyzji jest dobro własne rodziny, czyli dobro(byt) dzieci i innych członków, tworzących osobliwą więź bycia razem. Taki rodzaj rodzicielstwa wydaje się wolny od przynależności klasowo-warstwowej, od poziomu kulturalnego i ekonomicznego rodziny, od norm i konwenansów nakazujących żyć, jesz-

1 Y.N. Harari, Sapiens. A Brief History of Humankind, London 2014, s. 439, a także: M. Biedroń, Wptyw kultury indywidualizmu na relacje między rodzicami i dziećmi, [w:] Dziecko w zmieniającej się przestrzeni życia. Obrazy dzieciństwa, red. J. Izdebska, J. Szymanowska, Białystok 2009, s. 245-264; E. Dybowska, Upbringing and Socialization of a Child in the Family in the Era of Consumer Culture, Pedagogika Rodziny. Family Pedagogy, 2017, 7(4), s. 131-141.

2 M. Ściupider-Młodkowska, Miłość w epoce Ja. Studium socjopedagogiczne, Poznań 2018; taże: Rodzina i miłość w epoce Ja, Studia Pedagogica Ignatiana, 2019, 2, s. 102-118. 
cze do niedawna $w$ jedynie akceptowanym i petryfikowanym układzie trzech m: miłość, małżeństwo, macierzyństwo (z mniejszym udziałem ojcostwa, ale z większym udziałem dziadków). Dokonywanie owych „wolnych” wyborów oznacza niejednokrotnie uległość wobec silnej presji społecznej, narzucającej "dobrą" edukację, w celu „dobrze" płatnej pracy oraz presji i oczekiwań kulturowych wobec stwarzania "dobrych" warunków rozwojowych. Sytuacja rodziców jest zatem pełna napięć i uwikłania w niejednoznaczne wybory. Rodzice świadomie decydując się na rodzicielstwo, chcą odpowiedzialnie zapewnić dostatnie (dobre) warunki rozwojowe dzieciom, co niejednokrotnie oznacza konieczność kredytów mieszkaniowych oraz innych form wsparcia na cele edukacyjno-rozwojowe, czy zdrowotne, względem swoich dzieci.

„Emocjonalny kapitalizm"3 ${ }^{3}$ rodzicielstwa jest niezwykle bolesny w skutkach. Wyalienowani od pozostałych członków wspólnoty rodzinnej rodzice dbając o swoje latorośle, muszą każdego dnia zupełnie sami mierzyć się z wielością dokonywanych wyborów, a każdy z nich jest poddany "ukrytej” krytyce i ingerencji środków medialnych, grup oraz sieci pseudonaukowych ekspertyz i rynku, narzucającego wzorce prawidłowego rodzicielstwa. Nierówność sił $\mathrm{w}$ rodzicielstwie jest zatem związana nie tylko z różnym kapitałem społeczno-kulturowym, który rodzice otrzymują przed rodzicielstwem, ale z gigantyczną siłą oddziaływań kultury, narzucającej wzorce bycia od-

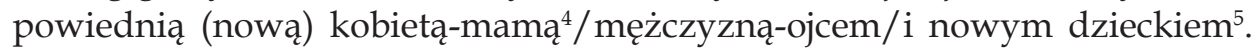
W ten sposób uwidaczniają się problemy, związane z socjalizacją i zderzeniem kultur jednego wzorca, czyli konfliktów wewnątrz wielu rodziców, którzy z jednej strony silnie przyswoili tradycyjny schemat patriarchatu, $z$ drugiej - źle rozumieją kulturowy feminizm, co prowadzi do kryzysów i wypalenia w pełnieniu ról oraz obowiązków ojców i mam, zdezorientowanych co do swoich obowiązków i powinności. Jeśli brakuje równowagi i priorytetów w pełnieniu obowiązków rodzicielskich, dochodzi do ryzyka utraty kontroli rodzicielskiej i korzystania z zasobów pseudoekspertyz. Napięcia emocjonalne rodziców, którzy starają się zapewnić dobrobyt dzieciom kosztem wieloetatowej i czasochłonnej pracy, wiodą bardzo często do utraty więzi oraz wielu frustracji i ostatecznie mogą prowadzić do rozpadu rodziny. Będąc we wspólnocie, rodzina doświadcza współcześnie wyjątkowo trudnego zadania

${ }^{3}$ Określenie E. Illouz, które oznacza podwójny proces spajania się emocjonalnych relacji w ekonomice, powodując utowarowienie relacji szybkich, powierzchownych, konsumpcyjnych. Na proces ten wpływają definicje współczesnych relacji i więzów rodzinnych, intymnych i uczuciowych, tworząc je obarczonymi rynkiem. Por: E. Illouz, Cold Intimaces. The Making of Emotional Capitalism, Cambridge 2007.

4 A. Gromkowska-Melosik, Edukacja i (nie)równość społeczna kobiet. Studium dynamiki dostępu, Kraków 2001, s. 186-188.

${ }^{5}$ B. Sikora, Nowa matka, nowy ojciec, nowe dziecko: o nowym układzie sit w polskich rodzinach, Warszawa 2009. 
utrzymania poczucia bezpieczeństwa, miłości i uznania. Obecny w tych układach rodzinnych lęk przed porzuceniem i zdradą prowokuje różne zachowania rodziców uwikłanych w konsumpcjonizm, poświęcających swój czas pracy zarobkowej kosztem wychładzania więzi z dziećmi. Te i wiele innych sprzeczności sprawiają, że rodzice balansują na granicy pozoranckiej demokracji a infantylizmu/adultyzmu ${ }^{6}$ i fasadowej władzy nad dzieckiem. Znane wśród psychiatrów dziecięcych zjawisko triangulacji, czyli włączania do rozwiązywania konfliktów małżeńskich dzieci, niestety, upowszechnia się wśród matek i ojców, którzy nie rozumieją roli dziecka, obciążając go własnymi problemami. Zjawisko to znane jest zwłaszcza wśród mam przebywających w izolacji więziennej, co zostanie zasygnalizowane w dalszej partii artykułu.

Rodziny z dziećmi są niezwykłymi i osobliwymi grupami społecznymi, których łączy nie tylko więź pokrewieństwa, ale uczuciowość i miłość. Rodziny, które w wyniku przeobrażeń społeczno-kulturowych rekonstruują, czasem zastępują swoje funkcje i zadania w większej mierze powierzając je instytucjonalnym sektorom wsparcia, bliższe są modelowi partnerskiemu i demokratycznemu. $W$ takim rodzicielstwie, jeśli są utrwalane i promowane wartości zaufania, pozytywnego przywiązania i zaangażowania, które pozwalają współpracować i przenikną z poziomu mikro na poziom makrospołeczny, wówczas nie zachwieje się ład i stabilność całych struktur społecznych. W takich układach rodzice nie będą musieli konkurować z wyborem życia w pojedynkę, czy z dobrze płatną, choć angażującą czasowo pracą, nie będą musieli dopasowywać priorytetów życia rodzinnego do zastanych warunków kulturowych, także edukacyjnych, narzucających bezrefleksyjność i niejednokrotnie nie dopuszczających do głosu rodziców ${ }^{7}$. Godne podziwu są wybory rodziców będących $\mathrm{w}$ układach patchworkowych, którzy potrafią bardzo dobrze ze sobą kooperować w wielości i różnorodności ról podwójnych rodziców, dzieci, kolażu rodzeństwa i bliskich więzi. Stabilność i trwałość rodzin nie zależy wyłącznie od małżeńskich i rodzicielskich ról bezrefleksyjnie narzucanych i przyjmowanych, ale przede wszystkim od przywiązania członków rodziny i wzajemnego rozumienia swoistych kodów, różnych dla każdej rodziny. Zrozumienie tego pozwoli uniknąć wielu błędów w interpretacji i sporach co do tego, jaki wzorzec rodzicielstwa jest pożądany i słuszny; należy raczej zapytać, które zmiany pozwolą rodzicom wpływać na jakość relacji z dzieckiem, a które je zdecydowanie utrudniają. We

${ }^{6}$ B. Jankowiak, Adultyzm - uprzedzenia przeciwko młodym ludziom, Studia Edukacyjne, 2017, 46.

7 W. Segiet, Rodzina w relacji ze szkota. Zasadnicze watki, wybrane inspiracje, [w:] Środowiska uczestnictwa społecznego jednostek, kategorii i grup, red. J. Modrzewski, A. Matysiak-Błaszczyk, E. Włodarczyk, Poznań 2018, s. 453-464. 
współczesnej rodzinie można zauważyć postępujące osłabienie wewnętrznej struktury, dezorganizację życia rodzinnego, polegające na nie spełnianiu i zaniedbywaniu przez rodziców swoich zadań wobec dzieci. Często występuje zjawisko tak zwanej dezintegracji, na skutek osłabienia więzi uczuciowej między członkami rodziny, utraty poczucia wspólnoty rodzinnej, wewnętrznego ładu i spokoju. W takich przypadkach rodzice tracą autorytet, a tym samym możliwość rzeczywistego oddziaływania na dziecko ${ }^{8}$. Jak słusznie wskazuje A. Krukowski, w rodzinie zdezintegrowanej nie rozwija się u dziecka poczucie solidarności, przynależności do grupy społecznej, poczucie współodpowiedzialności za jej powodzenia. Nie kształtuje się poczucie więzi społecznej, a to wpływa niekorzystnie na dalsze odczuwanie problemów społecznych. Na zjawisko dezintegracji rodziny niemały wpływ wywiera obecnie atrakcyjność zawodowych i społecznych spraw rodziców. Nie mają oni ochoty i siły na budowanie atmosfery "gniazda rodzinnego". Są zbyt zajęci karierą zawodową, pogonią za pieniądzem i sukcesem. Problemy dzieci są bardzo dalekie rodzicom. Wytwarza się wówczas atmosfera chłodu, uczuciowej oschłości, co sprzyja nawiązywaniu niekontrolowanych kontaktów pozarodzinnych, prowadzących łatwo na manowce. Mówiąc o atmosferze moralnej w rodzinie, należy zwrócić uwagę na nierzadkie zjawisko, leżące u podłoża demoralizacji. Chodzi o zjawisko tak zwanej podwójnej moralności, to jest rozbieżności pomiędzy głoszonymi zasadami moralnymi a rzeczywistymi regułami postępowania $\mathrm{w}$ sprawach związanych $\mathrm{z}$ wykonywaniem zawodu, stosunków międzyludzkich, obowiązków obywatelskich ${ }^{9}$. Dziecko bardzo często nabywa treści niekontrolowane i niekorzystnie oddziałujące na nie. W dalszej części tekstu przyjrzymy się macierzyństwu realizowanemu w warunkach penitencjarnej izolacji.

\section{Zniewolone macierzyństwo}

Macierzyństwo jest najczęściej spełnianiem kulturowej roli matki. Istnieje optimum spełniania tej roli wówczas, kiedy matki realizują kulturowo określone role społeczne, ale $\mathrm{w}$ społeczeństwie polskim funkcjonują także matki niemieszczące się w tym przedziale. Są to kobiety, które łamią wzór kulturowy macierzyństwa, a ich zachowania przekraczają normy ładu społecznego. Mowa o matkach pełniących swe role w warunkach izolacji i niewoli więziennej. Kobiety, u których często wadliwe wychowanie, traumatyczne przeżycia, ubogie kulturowo środowisko, które nie zaspokajało potrzeb psychicznych i nie nauczyło kobiety otwartej postawy wpływa destrukcyjnie na

${ }^{8}$ O. Lipkowski, Resocjalizacja, Warszawa 1976, s. 3.

9 A. Krukowski, Problemy zapobiegania przestępczości, Warszawa 1982, s. 21. 
jej nastawienia do rodzicielstwa i wzorce pełnienia roli matki ${ }^{10} . \mathrm{W}$ aresztach śledczych i zakładach karnych przebywa 2760 kobiet, stanowiących 3,7 procent populacji więziennej, liczącej około 74 tysięcy osadzonych ${ }^{11}$. Osadzone $\mathrm{w}$ polskich więzieniach kobiety $\mathrm{w}$ większości zastępują ojca i pełnią role macierzyńskie $^{12}$. Znaczenie matki w procesie pierwotnej socjalizacji dziecka jest szczególne. Kobieta zgodnie ze skryptami kulturowymi roli macierzyńskiej odpowiada za ciążę, poród, karmienie i pielęgnowanie potomstwa.

Od kobiecej roli matki oczekuje się między innymi ekspresji uczuć, serdeczności, ciepła, wyrozumiałości, tworzenia atmosfery emocjonalnej w rodzinie, zrozumienia, zaspokojenia potrzeb innych, wprowadzenia dziecka w krąg szerszej rodziny i tradycji ${ }^{13}$. To w szczególności zachowania matki zapewniają dziecku bezpieczeństwo i budują poczucie przywiązania ${ }^{14}$. Obecność matki w życiu dziecka ma niebagatelny wpływ na całokształt rozwoju psychicznego i fizycznego dziecka ${ }^{15}$. Zdaniem Kazimierza Pospiszyla, mimo naturalnego posłannictwa kobiety do roli macierzyńskiej, trudno przewidzieć, jak macierzyństwo będzie przebiegało ${ }^{16}$. Macierzyństwo jako bardzo intensywne przeżycie w życiu kobiety, często jest przyrównywane do posłannictwa, życiowej misji. Przynosi ogrom wyzwań oraz nieoczekiwanych sytuacji. Między dzieckiem i matką w pierwszych latach życia wytwarza się więź, która dzięki rozszerzaniu się zasobu doświadczeń sensoryczno-emocjonalnych, $\mathrm{w}$ dalszej kolejności powoduje nasilenie związków emocjonalnych z ojcem, rodzeństwem, rówieśnikami i innymi osobami ${ }^{17}$. Matka jest najważniejszą osobą w życiu każdego dziecka, odpowiedzialną za jego rozwój. Jakość więzi matki i dziecka jest bardzo istotna ${ }^{18}$. Często uważa się, że więź łącząca matkę z dzieckiem stanowi najtrwalszą i najpiękniejszą więź międzyludzką. Pierwotny mechanizm przywiązania matki do dziecka ma ścisły związek z rozwojem więzi emocjonalnej, co słusznie podkreśla M. Bidzan. Zdaniem autorki, pierwotna więź matki i dziecka pojawia się w pierwszej kolejności jako wrodzona reakcja, mająca charak-

${ }_{10}$ M. Mądry, Zakłócenia w odgrywaniu roli matki - wybrane zagadnienia [w:] Kontrowersje wokót socjalizacji dziewcząt i kobiet, red. A. Matysiak-Błaszczyk, B. Jankowiak, Poznań 2016, s. 137.

11 G. Linder, Izolowane, Forum Penitencjarne, 2017, 230, s. 19.

${ }_{12}$ H. Reczek, Macierzyństwo w więzieniu, [w:] www.sw.gov.pl

13 Za: R. Grochocińska, Życie dziecka w warunkach tymczasowej i stałej separacji matki $i$ ojca, Gdańsk 1992, s. 8.

14 D. Senator, Główne tezy teorii przywiązania, [w:] Bliskość w rodzinie. Więzi w dzieciństwie a zaburzenia w dorosłości, red. B. Tryjarska, Warszawa 2012, s. 36.

15 J. Bowlby, Child Care and The Growth of Love, London 1953.

16 K. Pospiszyl, Psychologia kobiety, Warszawa 1986.

${ }_{17}$ M. Marczak, Petnienie roli matki przez kobiety pozbawione wolności, [w:] Misja Stużby Więziennej a jej zadania wobec aktualnej polityki karnej i oczekiwań społecznych. IV Polski Kongres Penitencjarny, red. W. Ambrozik, H. Machel, P. Stępniak, Poznań - Gdańsk - Warszawa 2008, s. 458.

${ }_{18}$ M. Bidzan, Nastoletnie rodzicielstwo. Perspektywa psychologiczna, Gdańsk 2013, s. 141. 
ter autonomiczny, później powstają relacje emocjonalne dziecka z innymi ludźmi. Współcześnie pojęcie instynktu przekształciło się w pojęcie przywiązania czy też więzi ${ }^{19}$. Więź oznacza łączność emocjonalną, która powstaje pomiędzy noworodkiem a opiekunem w ciągu pierwszych dni życia dziecka. W początkowym okresie życia, obejmującym niemowlęctwo, wiek poniemowlęcy i przedszkolny, rodzina, a w szczególności matka odgrywa szczególnie ważną rolę w procesie socjalizacji dziecka. Pierwsze kontakty społeczne nawiązuje ono z matką, ojcem, rodzeństwem oraz innymi domownikami ${ }^{20}$. Małe dziecko kiedy uczy się chodzenia, prawidłowego posługiwania rękoma i mówienia, nie pełni jeszcze społecznych ról. Ta wczesna faza akulturacji polega na prostych przystosowaniach zachowania w sytuacjach kulturowo i społecznie uregulowanych do zachowań dzieci starszych i dorosłych. Z tymi elementarnymi doświadczeniami, opanowawszy mowę i chód, dziecko wchodzi w środowisko sąsiedzkie i przedszkolne. Nawiązuje kontakty z dziećmi i dorosłymi. Włącza się do zabawowych grup rówieśniczych, podejmuje czynne role w zabawie lub pełni rolę kibica w zabawach dzieci starszych. Uczestnicząc z życiu przedszkola, wchodzi do jego formalnych i nieformalnych grup dziecięcych, podejmując w nich role realne, jak i fikcyjne. Uczestnicząc $w$ tych rozszerzonych kręgach społecznych, dziecko uzupełnia i pogłębia wcześniejsze doświadczenia zdobyte we własnej rodzinie. W tym okresie odzwierciedla podstawowe wartości i formy współżycia subkultury, w której wzrasta. Najistotniejszym osiągnięciem tego wieku jest wszakże odkrycie siebie $\mathrm{w}$ doświadczeniach $\mathrm{z}$ grupą, siebie jako „ja” społecznego - własnej jaźni subiektywnej ${ }^{21}$. W procesie socjalizacji pierwotnej niezwykle często abecadło życia społecznego przekazywane jest przez rodziców. W procesie socjalizacji dziecka oddziaływanie matki i ojca ma raczej charakter spontaniczny, nie wynikający niejednokrotnie z określonego programu działalności wychowawczej. Z tych względów analizując proces wychowania społecznego, F. Znaniecki twierdzi, że

mimo wszystko co się mówi i pisze o ważności wychowania rodzicielskiego, każde społeczeństwo oczekuje od rodziców głównie nieprzeszkadzania, a w najlepszym razie współdziałania za swymi specjalnymi instytucjami wychowawczymi i pozostawia im tylko te zadania, których jeszcze żadnym instytucjom powierzyć nie można ${ }^{22}$.

Działanie matki w zakresie społecznego rozwoju dziecka dokonuje się za pośrednictwem modeli zachowania jej członków. Mogą to być zarówno

${ }^{19}$ L. Brannon, Psychologia rodzaju, przekł. M. Kacmajor, Gdańsk 2002, s. 251.

${ }^{20}$ A. Matysiak-Błaszczyk, B. Jankowiak, Znaczenie relacji przywiazania w cyklu życia człowieka. Analiza wybranych aspektów bliskich relacji, Studia Edukacyjne, 2017, 44, s. 195-208.

${ }^{21}$ J. Szczepański, Elementarne pojęcia socjologii, Warszawa 1970, s. 135-139.

${ }_{22}$ F. Znaniecki, Socjologia wychowania, tom I, Warszawa 1928, s. 114. 
wzory zgodnego współżycia i współdziałania, jak też modele sytuacji konfliktowych i działań aspołecznych. Funkcjonują one na zasadzie mechanizmu mimowolnego naśladownictwa, stanowiąc podstawę nabywania przez dziecko postaw i sposobu postępowania członków rodziny ${ }^{23}$. Należy zaznaczyć, że nie zawsze identyfikacja dziecka z rodzicami oparta na więzi z nimi jest wychowawczo korzystna.

$W$ rodzinach zdemoralizowanych, przestępczych dziecko identyfikując się z rodzicami, przejmuje często wzory zachowań społecznie ujemnych i samo się wykoleja ${ }^{24}$. Niekorzystna atmosfera życia rodzinnego stanowi negatywny stosunek uczuciowy rodziców, szczególnie matki do dziecka, budzący u niego poczucie braku bezpieczeństwa, zbędności, braku miłości, co $\mathrm{w}$ następstwie prowadzi do utraty więzi uczuciowej z rodziną, niechęci do przebywania w domu i prób zaspokojenia potrzeb psychicznych poza domem, często $\mathrm{w}$ przestępczych grupach rówieśniczych. Z. Zaborowski do przyczyn zaburzeń $\mathrm{w}$ rozwoju społecznym dzieci zalicza: odrzucenie przez rodziców, niestałość emocjonalną rodziców i odrzucenie od matki ${ }^{25}$.

Odrzucenie stanowi następstwo braku zaspokojenia przez rodziców występującej u dziecka potrzeby afiliacji, czyli związków uczuciowych, przejawiające się w niechętnym traktowaniu go, braku objawów życzliwości, lekceważącym stosunku do jego podstawowych potrzeb. Sytuacja taka może zachodzić wówczas, kiedy rodzice nie pragnęli przyjścia na świat dziecka, gdy traktują je jako przeszkodę w realizacji osobistych planów życiowych lub też odnoszą się doń niechętnie, gdyż jest nieurodziwe, ułomne, mało uzdolnione. Odrzucenie przez rodziców, szczególnie zaś przez matkę, wyzwala u dziecka stan niepokoju połączonego z wrogością oraz wystąpienie takich zaburzeń w zachowaniu, jak agresja, upór, negatywizm, wycofywanie się, bierność i apatia ${ }^{26}$.

Niestałość emocjonalna stanowi konsekwencję pewnych indywidualnych cech osobowości rodziców. Sprawiają one, że ich stosunek emocjonalny do dziecka ulega stałym zmianom, zaś objawy nadmiernej życzliwości i sympatii występują na przemian z symptomami niechęci i wrogości. Oddzielenie od matki polega na utracie kontaktu z nią, co uniemożliwia zaspokojenie podstawowych potrzeb dziecka. Może to być spowodowane długotrwałym pobytem w szpitalu, zakładzie karnym, wyjazdem matki i tym podobnymi. Oddzielenie od matki wywiera szczególnie niekorzystny wpływ na rozwój społeczny dziecka, powodując wystąpienie tak zwanej choroby sierocej ${ }^{27}$. Barbara Jarzę-

\footnotetext{
${ }^{23}$ Z. Skorny, Proces socjalizacji dzieci i młodzieży, Warszawa 1987, s. 59.

${ }^{24}$ Tamże, s. 21.

25 Z. Zaborowski, Koncepcja rozwoju społecznego dziecka, Kwartalnik Pedagogiczny, 1969, 1.

${ }^{26}$ Tamże.

${ }^{27}$ Tamże.
} 
bowska-Baziak zdefiniowała „syndrom więzienny” jako sytuację dzieci, które przyzwyczaiły się do otaczającego je świata więziennego, co zdaniem autorki niekorzystnie wpływa na ich rozwój poznawczy i osobowościowy ${ }^{28}$. Przeżycia dzieci związane z opuszczeniem domu matki i dziecka, z percepcją nowych bodźców tkwiących $\mathrm{w}$ środowisku otwartym - wolnościowym określono jako „szok wolności” 29 . Z badań B. Skafiriak wynika, że skazane kobiety-matki sprawują pieczę, a faktycznie socjalizują więzienne dzieci, przekazując im wzory zachowań nieodpowiadające standardowym wzorom funkcjonowania rodzi$n^{30}$. Autorka wskazuje, że $81 \%$ skazanych kobiet z więziennego domu matki i dziecka nie pozostawało w związku małżeńskim, 56\% skazanych matek stanowiły kobiety, które nie pozostawały w związku małżeńskim i miały więzienne dziecko oraz dzieci pozawięzienne, $25 \%$ pozostawało $w$ związku małżeńskim i miały tylko jedno dziecko, które pozostawało z nimi w więziennym Domu Matki i Dziecka w Zakładzie Karnym w Krzywańcu, u 66\% skazanych kobiet - więziennych matek stwierdzono dysfunkcjonalność macierzyńską skazanej kobiety-matki przed pobytem $\mathrm{w}$ zakładzie karnym wobec posiadanych dzieci. Autorka badań stwierdza, że na dziesięć skazanych kobiet-matek przebywających w więziennym domu matki i dziecka, tylko trzy uzewnętrzniały funkcjonalną postawę macierzyńską wobec dziecka. W przypadku $82 \%$ skazanych kobiet stwierdzono dysfunkcjonalność środowiska rodziny pochodzenia. Zatem, zdaniem B. Skafiriak, więzienne matki w fazie aktywnego macierzyństwa nie mają utrwalonych kompetencji do pełnienia roli macierzyńskiej według oczekiwań standardowych, bo ich matki takich wzorów im nie przekazały. Większość skazanych kobiet-matek z Domu Matki i Dziecka w Zakładzie Karnym w Krzywańcu były córkami matek ujawniających zjawiskowe formy patologii społecznej, dysfunkcjonalność macierzyńską, które zwłaszcza wędrowały od partnera do partnera, były uzależnione od alkoholu, zaniedbywały swoje obowiązki wobec dzieci. Kobiety - więzienne matki, które były wychowywane w warunkach kulturowo zaniedbanych posługują się wzorami komunikacji oraz kodem zachowań swojego środowiska i właśnie taki kapitał kulturowy (wiedzę, umiejętności i zachowanie) przekazują swojemu dziecku we wczesnej fazie jego procesu socjalizacji, przy tym jeszcze dokonującego się w kontekście sytuacji życiowej skazanej matki, w warunkach jej izolacji więziennej ${ }^{31}$ Z ba-

${ }^{28}$ B. Jarzębowska-Baziak, Problem macierzyństwa w zakładzie karnym, [w:] Doświadczenia i perspektywy systemu penitencjarnego w Polsce. Materiały ogólnopolskiej konferencji zorganizowanej w dniach 12-13 grudnia 1985 roku, red. T. Szymanowski, A. Rzepiński, Warszawa 1987, s. 246.

${ }^{29}$ Tamże.

${ }^{30}$ B. Skafiriak, Próba prezentacji konkluzji na temat więziennego macierzyństwa w dyskursie naukowym pedagogiki socjalizacyjnej Profesora Jerzego Modrzewskiego, [w:] Pedagogika w społeczeństwie - społeczeństwo w pedagogice. Księga Jubileuszowa poświęcona Profesorowi Jerzemu Modrzewskiemu w 70. rocznice urodzin, red. A. Matysiak-Błaszczyk, E. Włodarczyk, Poznań 2016, s. 425-427.

${ }^{31}$ Tamże, s. 426. 
dań B. Skafiriak ${ }^{32}$ wynika także, że niektóre kobiety urodziły dzieci intencjonalnie, aby złagodzić sobie rygor sytuacji więziennej. Ponadto, były też i takie, które zachodziły w ciążę w czasie odbywania kary bezwzględnego pozbawienia wolności. $Z$ badań wynika również, iż $60 \%$ kobiet porzuca swoje dzieci, czyli były one bez dalszej identyfikacji ze swoim dzieckiem. Dlatego, znaczny odsetek dzieci po opuszczeniu zakładu karnego rozpoczyna swoją biografię $\mathrm{w}$ zastępczej rodzinie lub rodzinie pochodzenia matki, która już przecież niepomyślnie zsocjalizowała jednostkę ludzką, bądź innej formie opieki całkowitej poprzez ośrodki socjalizacyjne, resocjalizacyjne, zakład poprawczy, kończąc na pobycie w zakładzie karnym ${ }^{33}$. W przypadku 93\% skazanych kobiet stwierdzono przejawy patologii $\mathrm{w}$ zachowaniu, a tylko $7 \%$ populacji stanowiły kobiety niezdemoralizowane, które popełniły przestępstwo sytuacyjnie i nie wymagały resocjalizacji. Autorka badań stwierdza, że

model roli macierzyńskiej najczęściej jest odtwarzany z rodziny pochodzenia, a brak u kobiety prawidłowego wzorca roli matki wpływa na obniżenie poziomu jej przystosowania (lub jej brak) do macierzyńskiej aktywności. Odnosi się to zwłaszcza do kobiet o niskim stopniu uspołecznienia, które przejawiają powrotność do przestępstwa, niestałość w roli pracownika, nieodpowiednie postawy wobec prawa, społeczności, dominujące zainteresowanie sobą, niski poziom moralny, nieodpowiednie postawy wobec małżeństwa i macierzyństwa ${ }^{34}$.

Tęsknota i miłość, z jaką borykają się uwięzione przybiera na sile w tak specyficznym miejscu, jakim jest jednostka penitencjarna ${ }^{35}$.

W wielu przypadkach dopiero w sytuacji uwięzienia skazane kobiety zaczynają doceniać wartość macierzyństwa, jednocześnie zastanawiając się nad przyszłością dzieci i swoją ${ }^{36}$. I. Muszyńska podaje, że dla kobiet najgorszą sytuacją, z jaką muszą się zmagać $\mathrm{w}$ warunkach izolacji więziennej jest rozłąka z najbliższymi, szczególnie dziećmi.

Ich związek z rodziną, z mężem, z dziećmi lub innymi osobami najbliższymi jest zwykle bardzo silny i bardzo emocjonalny. Zdecydowanie gorzej niż mężczyźni znoszą izolację więzienną ${ }^{37}$.

W takich warunkach pojawia się także poczucie samotności i bezradności wobec przeszkód uniemożliwiających prawidłowe zaspokojenia podsta-

${ }^{32}$ Tamże, s. 425-427.

${ }^{33}$ Tamże

${ }^{34}$ Tamże, s. 430.

${ }^{35}$ M. Marczak, K. Mirosław, Funkcjonowanie kobiet w warunkach izolacji więziennej, [w:] Skuteczność oddziaływań penitencjarnych, red. M. Kuć, Lublin 2009, s. 120-121.

${ }^{36}$ M. Marczak, K. Mirosław-Nawrocka, Zakłady penitencjarne dla kobiet, [w:] Psychologia penitencjarna, red. M. Ciosek, B. Pastwa-Wojciechowska, Warszawa 2016, s. 184.

${ }^{37}$ H. Machel, Więzienie jako instytucja karna i resocjalizacyjna, Gdańsk 2003, s. 269. 
wowych potrzeb ${ }^{38}$. $\mathrm{Z}$ wielu badań wynika, że w rodzinach nieletnich i młodocianych przestępców częściej niż w rodzinach badanych nieprzestępców spotyka się złe warunki materialne i mieszkaniowe. Wynika to najczęściej z ograniczonych możliwości zawodowych rodziców, z ich zazwyczaj niskiego wykształcenia i przygotowania zawodowego. Sytuacji materialnej towarzyszą na ogół ograniczone zainteresowania kulturalne, prymitywizm potrzeb i stylu życia. Wśród tych aspektów środowiska rodzinnego, które wywierają silny negatywny wpływ na wykolejenie społeczne dzieci, wymienić również trzeba wykolejenie społeczne samych rodziców, przejawiające się zwłaszcza w postaci alkoholizmu, przestępczości (karalności), prostytucji ${ }^{39}$. Z badań A. Matysiak-Błaszczyk wynika, że skazane kobiety najczęściej pochodzą z domów, w których kumulowały się syndromy niekorzystnych czynników, takich jak: niskie wykształcenie rodziców, bezrobocie jednego lub obojga rodziców, panująca trudna sytuacja materialna $\mathrm{w}$ rodzinie, niejednokrotnie niespłacanie przez rodziców zobowiązań finansowych, uwikłanie od wielu lat w problemy alkoholowe oraz przejawiany chłód emocjonalny. W przekonaniu autorki badań, istnieje zależność pomiędzy wieloproblemowością rodzin pochodzenia skazanych matek a ich procesem praktykowania przestępczego stylu życia ${ }^{40}$. H. Reczek uważa, że macierzyństwo zmienia każdą kobietę, także przebywającą za więziennymi murami i dla wielu z nich dziecko staje się najważniejsze ${ }^{41}$. Dlatego, pobyt w instytucji domu matki i dziecka ma wyraźny sens. Skazane w trakcie odbywania kary pozbawienia wolności wraz ze swoim dzieckiem uczą się rozpoznawać uczucia własne oraz innych, nabierają umiejętności związanych z organizacją domu, przechodzą warsztaty z zakresu pielęgnacji i higieny dziecka oraz edukują się w kwestiach opieki i wychowania. Z kolei G. Lewandowski wskazuje, że macierzyństwo pozytywnie wpływa na kobietę, dzięki czemu czuje się ona dowartościowana, powoduje u niej wzrost poczucia przynależności, wzmacnia akceptację i miłość do dziecka oraz może stanowić czynnik eliminujący zachowania przestępcze ${ }^{42}$. U. Nowak dodaje, że więzienne domy matki i dziecka są ratunkiem dla wszystkich dzieci, którym grozi oddanie do domu dziecka i choroba sieroca. Los przebywającego w placówce opiekuńczo-wychowawczej oderwanego od matki dziecka więźniarki jest szczególnie bolesny, bowiem ani nie może ono zostać adoptowane, ani nie

${ }^{38}$ M. Marczak, K. Mirosław-Nawrocka, Zakłady penitencjarne dla kobiet, s. 185.

${ }^{39}$ H. Kołakowska-Przełomiec, Środowisko rodzinne w świetle badań kryminologicznych, [w:] Zagadnienia przestępczości w Polsce, red. J. Jasiński, Warszawa 1975, s. 177.

40 A. Matysiak-Błaszczyk, Więzienne macierzyństwo. Studium socjopedagogiczne, Poznań 2016, s. $257-258$.

${ }^{41} \mathrm{H}$. Reczek, Oddziatywania wychowawcze, realizowane w stosunku do osadzonych matek w Domu dla Matki i Dziecka przy Zakładzie Karnym nr 1 w Grudziądzu, [w:] Kobieta w więzieniu - polski system penitencjarny wobec kobiet w latach 1998-2008, red. I. Dybalska, Warszawa 2009, s. 225.

${ }^{42}$ G. Lewandowski, Kobieta w zakładzie karnym, Warszawa 1994. 
spotyka się z matką. Autorka stwierdza, że resocjalizacja przez miłość jest skuteczna ${ }^{43}$, jednak dodaje, że nikt nie twierdzi, że pobyt dziecka w więzieniu jest dla niego najlepszym rozwiązaniem. Kobiety znacznie gorzej niż mężczyźni znoszą rozłąkę z najbliższymi, szczególnie dziećmi. Brak możliwości wykonywania przypisanych im ról społecznych prowadzi do tęsknoty za rodziną. Są to sytuacje nadzwyczajnie trudne, które mogą prowadzić do wielu zaburzeń psychicznych, wycofania, stanów depresyjnych, chorób somatycznych, czy prób i aktów samobójczych. Skazane kobiety odbywające karę pozbawienia wolności wraz ze swoimi dziećmi, jak wynika z badań A. Matysiak-Błaszczyk, wyrażają głęboką nadzieję i wiarę, że ich dzieci nie powielą ich biograficznej ścieżki oraz nie zapamiętają pobytu w izolacji ${ }^{44}$.

\section{Zakończenie}

Współczesne rodzicielstwo zarówno w warunkach wolnych wyborów, jak i izolacji jest pełne napięć i nierówności. Źródłem dezorganizacji, czy niewłaściwych wzorców bycia mamą i tatą, jest w równym stopniu źle przyswojone uwarunkowanie psychiczne $\mathrm{z}$ rodzin pochodzenia oraz powielanie niewłaściwych wzorców i schematów rodzicielstwa, jak też paralelne w stosunku do tego mechanizmy manipulowania kodami kulturowymi, obiecującymi dobrobyt materialny, a prowadzącymi do osamotnienia i dewaluacji wspólnotowości.

W artykule starano się dostrzec konsekwencje socjalizacyjne dla aktorów - rodziców realizujących swoje role zarówno w warunkach wolnych wyborów, jak również izolacji. W konkluzji, należy przyznać, że badawcze rozumienie (M. Webera), wczuwanie (W. Diltheya), czy wreszcie „współczynnik humanistyczny" (F. Znanieckiego) pozwalają nie tylko na komentowanie i przyglądanie się zjawiskom, które mogą wzbudzać zamęt pedagogiczny. Należy pamiętać o konsekwencjach funkcji socjalizacyjnych, a więc sensie znaczeniu i schematach, jakie rodzice realizujący różne hybrydowe wzorce wielu rodzin nadają pokoleniom powielającym owe wzorce. Dlatego, ciekawym wnioskiem wymagającym dalszej empirii jest przyjęcie punktu widzenia zarówno rodzin dysfunkcyjnych, które powielają krzywdzące schematy ról rodzicielskich w izolacji, jak i rodzin z kręgu „eksperymentujących”, ponowoczesnych, nie zawsze będących świadomymi przenikania do następnych pokoleń socjalizacyjnych skryptów, które mogą zaburzyć bliskość więzi i trwałość relacji.

${ }^{43}$ U. Nowak, Dom Matki i Dziecka w Krzywańcu, [w:] Kobieta w więzieniu, s. 240.

${ }^{44}$ A. Matysiak-Błaszczyk, Więzienne macierzyństwo, s. 257-258. 


\section{BIBLIOGRAFIA}

Bidzan M., Nastoletnie rodzicielstwo. Perspektywa psychologiczna, Gdańsk 2013.

Biedroń M., Wptyw kultury indywidualizmu na relacje między rodzicami i dziećmi, [w:] Dziecko w zmieniającej się przestrzeni życia. Obrazy dzieciństwa, red. J. Izdebska, J. Szymanowska, Białystok 2009.

Bowlby J., Child Care and The Growth of Love, London 1953.

Brannon L., Psychologia rodzaju, przekł. M. Kacmajor, Gdańsk 2002.

Dybowska E., Upbringing and Socialization of a Child in the Family in the Era of Consumer Culture, Pedagogika Rodziny. Family Pedagogy, 2017, 7(4).

Grochocińska R., Życie dziecka w warunkach tymczasowej i statej separacji matki i ojca, Gdańsk 1992.

Gromkowska-Melosik A., Edukacja i ( nie)równość społeczna kobiet. Studium dynamiki dostępu, Kraków 2001.

Harari Y.N., Sapiens. A Brief History of Humankind, London 2014.

Illouz E., Cold Intimaces. The Making of Emotional Capitalism, Cambridge 2007.

Jankowiak B., Adultyzm - uprzedzenia przeciwko młodym ludziom, Studia Edukacyjne, 2017, 46.

Jarzębowska-Baziak B., Problem macierzyństwa w zakładzie karnym, [w:] Doświadczenia i perspektywy systemu penitencjarnego w Polsce. Materiały ogólnopolskiej konferencji zorganizowanej w dniach 12-13 grudnia 1985 roku, red. T. Szymanowski, A. Rzepiński, Warszawa 1987.

Kołakowska-Przełomiec H., Środowisko rodzinne w świetle badań kryminologicznych, [w:] Zagadnienia przestępczości w Polsce, red. J. Jasiński, Warszawa 1975.

Krukowski A., Problemy zapobiegania przestępczości, Warszawa 1982.

Lewandowski G., Kobieta w zakładzie karnym, Warszawa 1994.

Linder g., Izolowane, Forum Penitencjarne, 2017, 230.

Lipkowski O., Resocjalizacja, Warszawa 1976.

Machel M., Więzienie jako instytucja karna i resocjalizacyjna, Gdańsk 2003.

Marczak M., Petnienie roli matki przez kobiety pozbawione wolności, [w:] Misja Stużby Więziennej a jej zadania wobec aktualnej polityki karnej i oczekiwań społecznych. IV Polski Kongres Penitencjarny, red. W. Ambrozik, H. Machel, P. Stępniak, Poznań - Gdańsk - Warszawa 2008.

Marczak M., Mirosław K., Funkcjonowanie kobiet w warunkach izolacji więziennej, [w:] Skuteczność oddziaływań penitencjarnych, red. M. Kuć, Lublin 2009.

Marczak M., Mirosław-Nawrocka K., Zakłady penitencjarne dla kobiet, [w:] Psychologia penitencjarna, red. M. Ciosek, B. Pastwa-Wojciechowska, Warszawa 2016.

Matysiak-Błaszczyk A., Jankowiak B., Znaczenie relacji przywiąania w cyklu życia człowieka. Analiza wybranych aspektów bliskich relacji, Studia Edukacyjne, 2017, 44.

Mądry M., Zakłócenia w odgrywaniu roli matki - wybrane zagadnienia, [w:] Kontrowersje wokót socjalizacji dziewczat i kobiet, red. A. Matysiak-Błaszczyk, B. Jankowiak, Poznań 2016.

Nowak U., Dom Matki i Dziecka w Krzywańcu, [w:] Kobieta w więzieniu - polski system penitencjarny wobec kobiet w latach 1998-2008, red. I. Dybalska, Warszawa 2009.

Pospiszyl K., Psychologia kobiety, Warszawa 1986.

Reczek H., Macierzyństwo w więzieniu, w: www.sw.gov.pl

Reczek H., Oddziatywania wychowawcze, realizowane w stosunku do osadzonych matek w Domu dla Matki i Dziecka przy Zakładzie Karnym nr 1 w Grudziądzu, [w:] Kobieta w więzieniu polski system penitencjarny wobec kobiet w latach 1998-2008, red. I. Dybalska, Warszawa 2009. 
Segiet W., Rodzina w relacji ze szkoła. Zasadnicze watki, wybrane inspiracje, [w:] Środowiska uczestnictwa społecznego jednostek, kategorii i grup, red. J. Modrzewski, A. Matysiak-Błaszczyk, E. Włodarczyk, Poznań 2018.

Senator D., Główne tezy teorii przywiazania, [w:] Bliskość w rodzinie. Więzi w dzieciństwie a zaburzenia w dorosłości, red. B. Tryjarska, Warszawa 2012.

Sikora B., Nowa matka, nowy ojciec, nowe dziecko: o nowym układzie sit w polskich rodzinach, Warszawa 2009.

Skafiriak B., Próba prezentacji konkluzji na temat więziennego macierzyństwa w dyskursie naukowym pedagogiki socjalizacyjnej Profesora Jerzego Modrzewskiego, [w:] Pedagogika w społeczeństwie - społeczeństwo w pedagogice. Księga Jubileuszowa poświęcona Profesorowi Jerzemu Modrzewskiemu w 70. rocznice urodzin, red. A. Matysiak-Błaszczyk, E. Włodarczyk, Poznań 2016.

Skorny Z., Proces socjalizacji dzieci i młodzieży, Warszawa 1987.

Szczepański J., Elementarne pojęcia socjologii, Warszawa 1970.

Ściupider-Młodkowska M., Miłość w epoce Ja. Studium socjopedagogiczne, Poznań 2018.

Ściupider-Młodkowska M., Rodzina i miłość w epoce Ja, Studia Pedagogica Ignatiana, 2019, 2.

Zaborowski Z., Koncepcja rozwoju społecznego dziecka, Kwartalnik Pedagogiczny, 1969, 1.

Znaniecki F., Socjologia wychowania, tom I, Warszawa 1928. 